\begin{tabular}{|l|l|l|l|l|l|}
\hline J. Tek. Ling & Vol.10 & No.3 & Hal. 347 - 354 & Jakarta, Sept 2009 & ISSN 1441-318X \\
\hline
\end{tabular}

\title{
STATUS KONSORSIUM MIKROBA LOKAL PENDEGRADASI MINYAK
}

\author{
Wage Komarawidjaja ${ }^{1)}$ dan Esi Lysiastuti ${ }^{2)}$ \\ 1) Peneliti di Pusat Teknologi Lingkungan \\ 2) Peneliti di Balai Teknologi Lingkungan \\ Badan Pengkajian dan Penerapan Teknologi
}

\begin{abstract}
Abstrack
Laboratory observation were conducted to study the effect of media containing oil spill on microbial ability in utilizing oil spill as carbon sources. Microbial consortia which was isolated from Cepu oil spill sample was inoculated on the Bushnell-Haas (BH) media containing 5\% Cepu crude oil.

The experiment proved that microbes could be able utilizing oil as carbon source for their cell multiplication, the more the turbidity concentration increase, the more the microbial population rise. Concentration of oil dissolved trend and availability that was measured show a microbial surfactant generation. Furthermore, microbial density that was measured along experiment period indicate an increase in density.

The result indicate that remediation of oil spill study which is utilizing indigenous microbes as in situ bioremediation technologies can be implemented.
\end{abstract}

Keywords : Oil pollution, biodegradation, bioremediation, biosurfactant

\section{PENDAHULUAN}

\subsection{Latar Belakang}

Tumpahan minyak berupa minyak bumi biasa terjadi pada proses eksplorasi dan produksi minyak sebagai sumber energi. Tumpahan tersebut merupakan polutan yang dapat mengganggu ekosistem pada wilayah yang terkontaminasi. Salah satu cara untuk memulihkan lingkungan tersebut kembali ke keadaan semula adalah dengan menggunakan teknik bioremediasi. Bioremediasi sendiri merupakan suatu teknik pemulihan lingkungan yang tercemar dengan menggunakan mikroorganisme, fungi, ataupun tumbuh-tumbuhan sehingga dapat kembali ke keadaan semula1).

Biodegradasi polutan suatu lingkungan merupakan proses yang kompleks, yang sangat bergantung pada kondisi lingkungan,

jumlah polutan serta komposisi dari komunitas mikroba lokal (indigenous) di tempat tersebut. Bioremediasi merupakan salah satu cara yang kerap digunakan untuk mengatasi cemaran minyak mentah pada suatu lingkungan. Pengertian dari bioremediasi sendiri adalah proses penguraian limbah (pencemar) menggunakan agen biologi (mikroba) yang dilakukan dalam kondisi terkendali (controlled condition). Proses bioremediasi ini dapat terjadi secara alamiah oleh mikroba yang terdapat pada lingkungan tercemar (intrinsict bioremediation). Meskipun demikian, sering kali dilakukan beberapa hal untuk mempercepat proses tersebut. Contohnya dengan menambahkan mikroba (exogenous microbe), nutrien, donor dan atau akseptor elektron 2). Penambahan 
mikroba eksogenus, tentunya dilakukan dengan terlebih dahulu melakukan penelitian skala laboratorium sehingga dapat diketahui kinerja dari mikroba yang bersangkutan. Sedangkan penambahan nutrien dilakukan untuk mempercepat pertumbuhan mikroba lokal yang terdapat pada daerah tercemar. Contohnya adalah penambahan pupuk yang mengandung nitrogen, fosfor, dan kalium terbukti efektif meningkatkan kemampuan mikroba dalam mendegradasi minyak ${ }^{3}$.

Beberapa peneliti telah menyampaikan beberapa mikroba yang diketahui memiliki kemampuan dalam mendegradasi minyak antara lain : Pseudomonas aeruginosa, Serratia marcescens, Acinetobacter baumannii, Baccillus megaterium, Baccillus cereus, Fussarium vertiaculloide, dan Candida tropicalis ${ }^{4,5,6)}$. Namun pada wilayah yang terkontaminasi terkadang ditemukan mikroba lokal, yang telah teradaptasi dengan lingkungan dan jenis polutannya. Hal ini berkaitan dengan karakteristik dari lingkungan, serta jenis polutan itu sendiri. Mikroba tersebut dalam proses biodegradasi biasanya bekerja secara konsorsium. Konsorsium mikroba terdiri atas beberapa jenis mikroba dalam suatu lingkungan tertentu. Maka dari itu, sebelum dilakukan proses bioremediasi di lapangan, tahap awal yang harus dilakukan adalah melakukan isolasi terhadap mikroba lokal dari areal yang telah tercemar minyak bumi. Pada penelitian ini dilakukan isolasi mikroba untuk mengetahui kemampuan mikroba lokal dalam mendegradasi minyak yang berasal dari lokasi sumur minyak Cepu.

\subsection{Tujuan}

Penelitian ini bertujuan untuk mengetahui kemampuan dan stabilitas mikroba dalam mendegradasi mikroba.

\section{METODOLOGI}

\subsection{Alat dan Bahan}

Selama penelitian ini, peralatan yang digunakan antara lain meliputi inkubator, shaker, ruang laminar, peralatan gelas seperti cawan petri, erlenmeyer, vorteks, gelas piala, $\mathrm{pH}$ meter, high blower aerator, neraca analitik, penangas air, oven, autoklaf dan pengaduk magnetik (magnetic stirrer).

Sedangkan bahan-bahan yang digunakan mencakup akuades, larutan $\mathrm{NaCl}$ fisiologis, media Bushnell-Haas $(\mathrm{BH})$ dengan komposisi $\mathrm{MgSO}_{4} 0.2 \mathrm{~g} / \mathrm{L}, \mathrm{KH}_{2} \mathrm{PO}_{4}$ $1 \mathrm{~g} / \mathrm{L}, \mathrm{K}_{2} \mathrm{HPO}_{4} 1 \mathrm{~g} / \mathrm{L}, \mathrm{FeCl} 3.3 \mathrm{H} 2 \mathrm{O} 0.05 \mathrm{~g} / \mathrm{L}$, $\mathrm{CaCl} 2.2 \mathrm{H} 2 \mathrm{O} 0.02 \mathrm{~g} / \mathrm{L}$, yeast extract $12 \mathrm{~g} / \mathrm{L}$, $\mathrm{NH} 4 \mathrm{NO}_{3} 1 \mathrm{~g} / \mathrm{L}$. Selain itu juga digunakan media nutrien agar (NA) yang terdiri atas pepton $15 \mathrm{~g} / \mathrm{L}$, yeast extract $3 \mathrm{~g} / \mathrm{L}, \mathrm{NaCl} 6$ $\mathrm{g} / \mathrm{L}$, Glukosa $1 \mathrm{~g} / \mathrm{L}$, dan agar $12 \mathrm{~g} / \mathrm{L}$.

\subsection{Metoda}

Stok Isolat. Konsorsium mikroba yang digunakan selama penelitian merupakan hasil isolasi dari sampel minyak mentah (crude oil) dari sumur minyak yang diambil dari blok cepu ${ }^{7}$.

Desain Penelitian. Desain akuarium yang digunakan dalam penelitian ini disajikan pada Gambar 1. Akuarium terbuat dari bahan kaca dengan tutup atas yang terbuat dari bahan plastik. Setiap sekat (kompartemen) diberi keran yang digunakan untuk pengambilan sampel. Dalam penelitian ini digunakan tiga sekat yang diberi kode 0 untuk perlakuan kontrol, diberi kode $1 \mathrm{x}$ untuk perlakuan I, dan diberi kode $2 x$ untuk perlakuan II.

Kompartemen dengan kode 0 (Kontrol) adalah blanko yang diisi media $\mathrm{BH} 3 \mathrm{~L}$, crude oil $1 \mathrm{~L}$, air $2 \mathrm{~L}$, tanpa penambahan konsorsium mikroba. Sedangkan kompartemen dengan kode 1x (Perlakuan I) diisi komposisi yang sama dengan Kontrol, tetapi ditambah dengan kultur konsorsium mikroba 1 bagian (1500 ml). Adapun kompartemen dengan kode 2x (Perlakuan II) diberi perlakuan yang sama dengan perlakuan I, kemudian ditambah dengan jumlah mikroba yang sama, apabila dari hasil pengamatan telah terjadi perubahan. Tiap Kompartemen diberi aerasi tak terbatas dengan high blower aerator. 


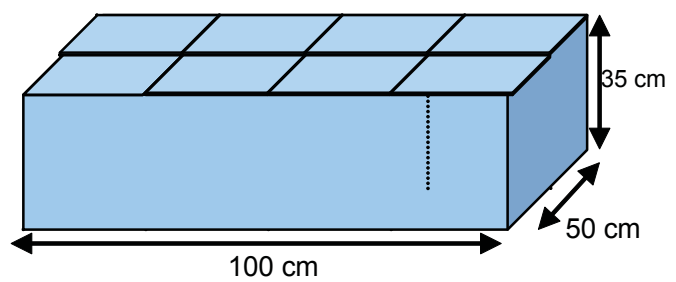

Gambar 1. Desain akuarium penelitian.

Parameter Yang Dianalisis. Pengambilan sampel untuk analisa dilakukan sebanyak delapan kali. Pengambilan sampel dilakukan setiap 3-5 hari sekali hingga pengambilan kelima dan seterusnya dilakukan pengambilan sampel tiap satu minggu sekali.

Pertumbuhan Mikroba. Penghitungan jumlah biomasa mikroba dilakukan dengan mengukur nilai absorban pada panjang gelombang $600 \mathrm{~nm}$. Sampel diencerkan terlebih dahulu dengan $\mathrm{NaCl}$ fisiologis $(0.9 \%)$ sehingga dihasilkan nilai absorban di bawah 1.

Total Mikroba-Lemak. Sebelum melakukan pengukuran mikroba yang terlarut dalam media tumbuh, terlebih dahulu mikroba yang terdapat pada sampel dipisahkan dengan disentrifus selama 10 menit. Kemudian $10 \mathrm{ml}$ supernatan diekstrak sebanyak dua kali dengan pelarut heksana pada corong pisah. Fraksi heksan selanjutnya ditampung dalam erlenmeyer dan disaring dengan kertas saring. Selanjutnya fraksi heksan yang didapat ditempatkan dalam labu lemak untuk kemudian didestilasi pada suhu $85^{\circ} \mathrm{C}$. Apabila terlihat kondensasi pelarut telah terhenti, labu lemak ditempatkan dalam eksikator selama 30 menit dan ditimbang bobot yang diperoleh. Kadar mikroba-lemak dinyatakan dalam nilai ppm.

\section{HASIL DAN PEMBAHASAN}

\subsection{Degradasi Minyak Oleh Konsorsium Mikroba}

Aktivitas degradasi minyak oleh mikroba adalah merupakan salah satu upaya pemanfaatan minyak oleh mikroba untuk menghasilkan energi yang dapat digunakan untuk hidup dan berkembangbiak. Lebih lanjut, metoda pemanfaatan minyak melalui degradasi dapat dibedakan menjadi dua yaitu, melalui proses aerobik dan anaerobik. Proses aerobik menggunakan oksigen sebagai akseptor elektron, sedangkan proses anaerobik menggunakan senyawa selain oksigen seperti sulfat, nitrat, mangan oksida, dan fumarat. Proses degradasi menggunakan mikroba akan melibatkan sistem enzimatis yang terdapat pada mikroba yang kemudian menghasilkan karbondioksida, air, dan bahan mineral seperti sulfat dan nitrat.

Selanjutnya sebagai suatu ilustrasi tentang lintasan (pathway) degradasi terhadap senyawa alkana (salah satu komponen minyak mentah) dapat dilihat pada tahapan yang disajikan pada Gambar 2. Proses tersebut terjadi secara aerobik dengan melibatkan oksigen sebagai akseptor elektron eksternal. Proses aerobik merupakan proses yang lebih mudah dan efisien karena dibutuhkan energi aktifasi yang lebih kecil dan menghasilkan energi bebas yang tinggi ${ }^{5)}$. Sebagian besar mikroba menyerang rantai karbon paling ujung dan menghasilkan senyawa alkohol primer (terminal oxidation), meskipun ada beberapa mikroba yang menyerang rantai karbon kedua sebelum ujung (subterminal oxidation) dan menghasilkan senyawa alkohol sekunder ${ }^{3)}$. Selanjutnya seperti digambarkan pada Gambar 2 adalah merupakan salah satu contoh subterminal oxidation.

Enzim monooksigenase sebagaimana diketahui memiliki peran dalam tahap awal lintasan mengoksidasi alkana menjadi senyawa alkohol sekunder. Pada akhir lintasan didapat dua senyawa yaitu, asam asetat dan asam karboksilat yang dapat digunakan sebagai prekursor dalam lintasan $\beta$-oksidasi. Lintasan $\beta$-oksidasi merupakan lintasan katabolisme lemak yang menghasilkan energi yang dapat digunakan oleh mikroba. 
Senyawa kimia yang terdapat pada minyak mentah dapat dibagi menjadi lima kelompok yaitu, minyak jenuh, senyawa aromatik, asphalten dan resin, komponen non-minyak yang biasa disingkat NOS (Nitrogen, Oksigen, Sulfur), serta senyawa porfirin yang berasal dari degradasi klorofil yang berbentuk kompleks vanadium (V) atau nikel $(\mathrm{Ni})^{8}$. Oleh karena itu, penting diketahui informasi mengenai konsorsium mikroba yang dapat menggunakan beragam senyawa pada minyak mentah.

Selanjutnya pengematan pengaruh konsorsium mikroba dalam aktivitas degradasi minyak dilakukan dengan metode gravimetri yaitu, dengan penetapan Total
Lemak-Minyak. Prinsip dari metode tersebut adalah mengekstrak senyawa-senyawa yang dapat berikatan (tertarik) dengan pelarut yang digunakan yaitu, heksana.

Heksana yang bersifat nonpolar akan berikatan dengan senyawa yang memiliki sifat yang sama. Dari sampel yang dianalisa, senyawa yang memiliki kecenderungan untuk terekstrak oleh heksana antara lain komponen minyak mentah itu sendiri, ataupun senyawa hasil proses biodegradasi komponen minyak mentah oleh mikroba. Contohnya adalah asam karboksilat atau asam lemak (Gambar 2) yang terbentuk dari hasil subterminal oxidation alkana oleh kerja enzim mikroba.

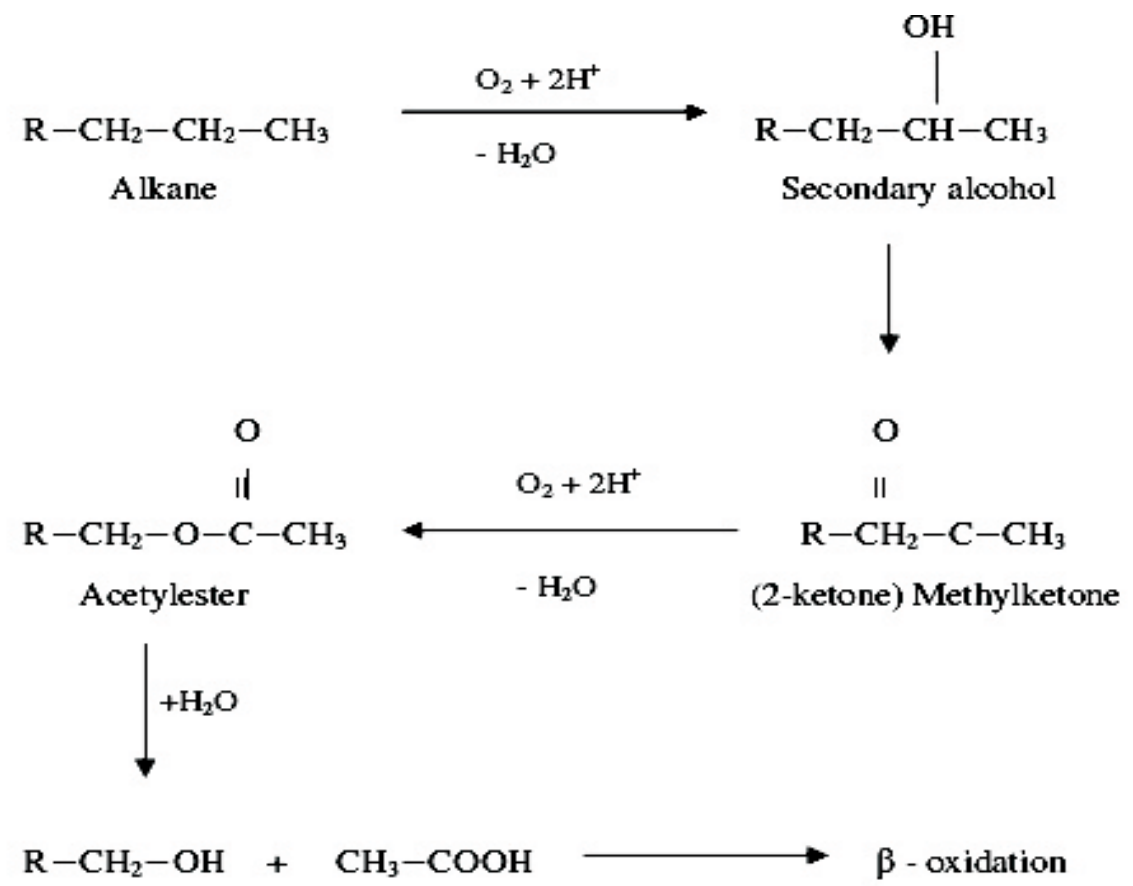

Primary alcohol Acetic acid

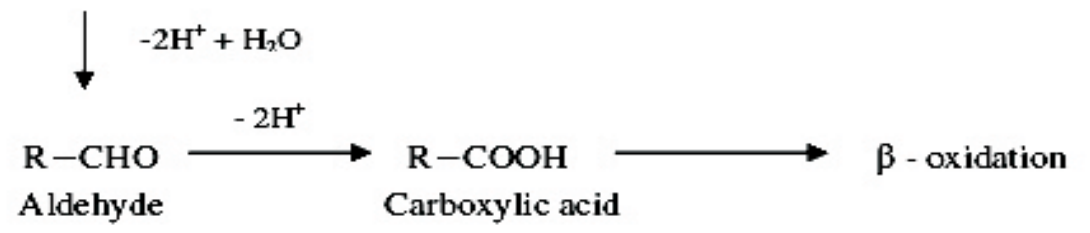

Gambar 2. Lintasan subterminal oxidation alkana (Atlas dan Bartha 1998 dalam Okoh 2006) ${ }^{3)}$. 
Lebih lanbjut aktivitas degradasi minyak oleh konsorsium mikroba disajikan pada Gambar 3 yang merupakan gambaran aktivitas dari kelompok kontrol, perlakuan $1 x$ dan perlakuan $2 x$. Apabila dibandingkan dengan kontrol, secara umum terlihat bahwa konsentrasi lemak-minyak lebih tinggi pada perlakuan 1x. Hal tersebut berkaitan erat dengan peran biosurfaktan dari mikroba yang meningkatkan kelarutan minyak mentah dalam media. Minyak yang larut dalam media kemudian terekstrak oleh fraksi heksana ketika proses analisis dan memberikan hasil yang lebih besar. Dari data yang fluktuatif dapat dilihat bahwa proses pelarutan minyak mentah terjadi karena adanya pembentukan biosurfaktan berlangsung dalam beberapa tahap. Tahap awal, mikroba hanya melarutkan sedikit atau sebagian minyak dalam media untuk digunakan sebagai sumber karbon. Hal tersebut dapat disebabkan karena mikroba masih dapat memanfaatkan sumber karbon yang terdapat pada media (yeast extract). Tahap selanjutnya yaitu, ketika sumber karbon semakin sedikit membentuk kembali biosurfaktan untuk dapat melarutkan minyak ke dalam media. Demikian seterusnya hingga seluruh minyak (sumber karbon) yang tersedia telah habis terpakai oleh mikroba.

Konsentrasi minyak terkecil yang larut dalam media untuk kelompok kontrol teramati pada hari ke-0, sedangkan untuk kelompok perlakuan $1 \mathrm{x}$ teramati pada hari ke-30, sebesar $445 \mathrm{ppm}$, sedangkan untuk pelakuan $2 x$ teramati konsentrasi minyak terkecil pada hari ke-0 atau ketika mikroba belum memproduksi biosurfaktan.

Selanjutnya, setelah terbentuk biosurfaktan dalam jumlah besar pada hari ke-6 yang ditandai dengan konsentrasi minyak terlarut $>1000 \mathrm{ppm}$ (perlakuan $1 \mathrm{x}$ 1180ppm dan perlakuan 2x mencapai 11610 ppm), mikroba mulai melakukan aktivitas biodegradasi baik pada perlakuan $1 x$ maupun perlakuan $2 x$, sehingga konsentrasi minyak terlarut menurun mencapai nilai terkecil 495 ppm karena digunakan oleh mikroba sebagai sumber karbon. Selain konsentrasi biosurfaktan pada hari ke 6 atau perioide pengamtan 3 meningkat, kepadatan mikroba pengamatan pun bertambah sebagaimana disajikan pada Gambar 4.

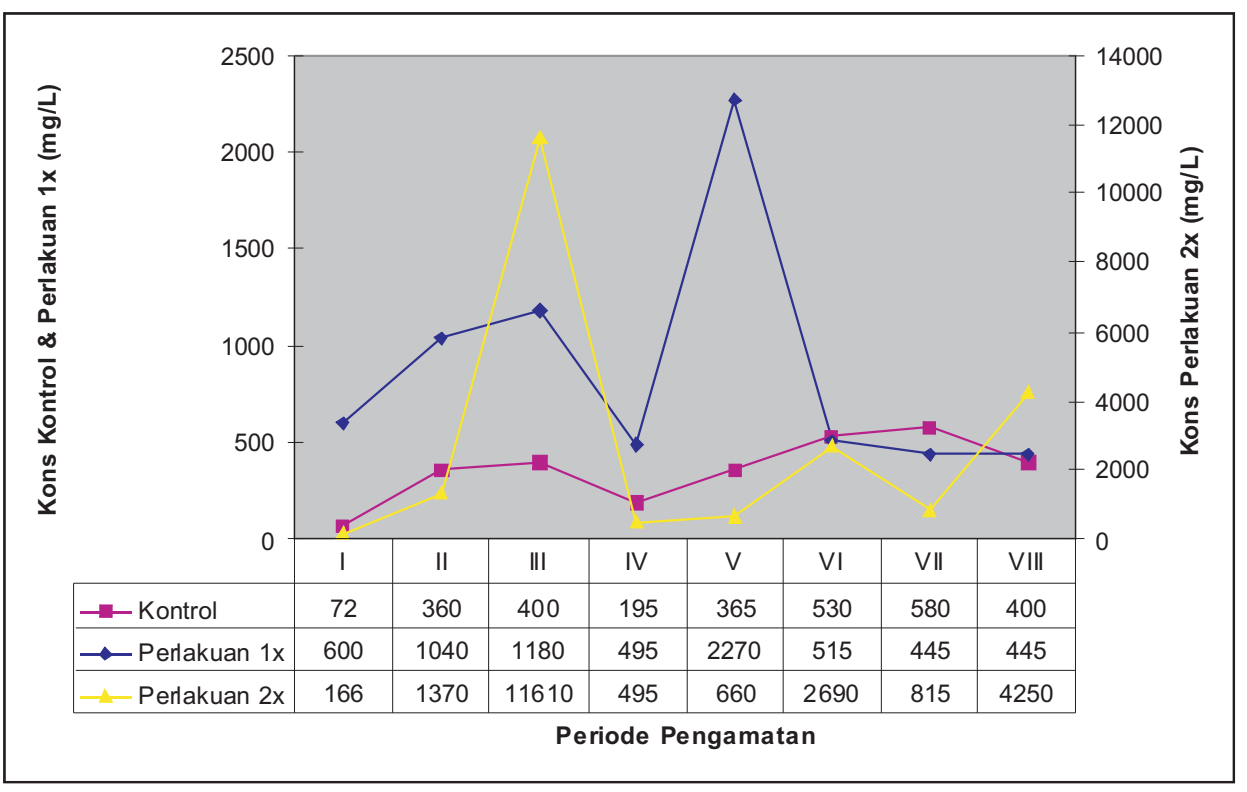

Gambar 3 Konsentrasi Lemak-Minyak terlarut pada kelompok kontrol, perlakuan 1x dan perlakuan 2x. 
Peningkatan kepadatan mikroba perlakuan I dan Perlakuan II dimulai pada pengamatan III dan sebaliknya untuk perlakuan kontrol terjadi penurunan kepadatan mikroba sebagaiamana disajikan pada Gambar 4. Hal ini terjadi diduga kuat sebagai akibat pasokan sumber karbon asal minyak yang bertahap meningkat sebagaimana digambarkan pada Gambar 3 sebagai kelarutan minyak dalam media kultur yang dimungkinkan karena bantuan biosurfaktan yang dibentuk oleh konsorsium mikroba yang berkembang pada media kultur pengujian tersebut. Ketersediaan minyak terlarut tersebut berkaitan erat dengan diproduksinya surfaktan oleh mikorba yang tumbuh pada media kultur kajian.

Namun adanya penurunan konsentrasi minyak terlarut pada pengamatan IV dan peningkatan konsentrasi minyak terlarut pada pengamatan $\mathrm{V}$, ternyata pada pengamatan yang sama kepadatan mikorba relatif rendah. Kondisi ini dimungkinkan terjadi karena pasokan minyak terlarut pada pengamatan IV yang terbatas, sehingga meskipun pada pengamatan $\mathrm{V}$ terjadi peningkatan konsentrasi minyak terlarut ternyata tidak langsung meningkatkan kepadatan mikroba. Namun demikian secara keseluruhan terjadi peningkatan kepadatan mikrorba sejalan dengan tersedianya sumber karbon dari minyak yang terlarut dalam media kultur kajian tersebut. Kondisi ini diduga terjadi, karena mikroba yang tumbuh pada periode pengamatan I sampai $V$ masih dalam tahap aklimatisasi, pada periode pengamatan VI sampai delapan kepadatan mikroba terus meningkat.

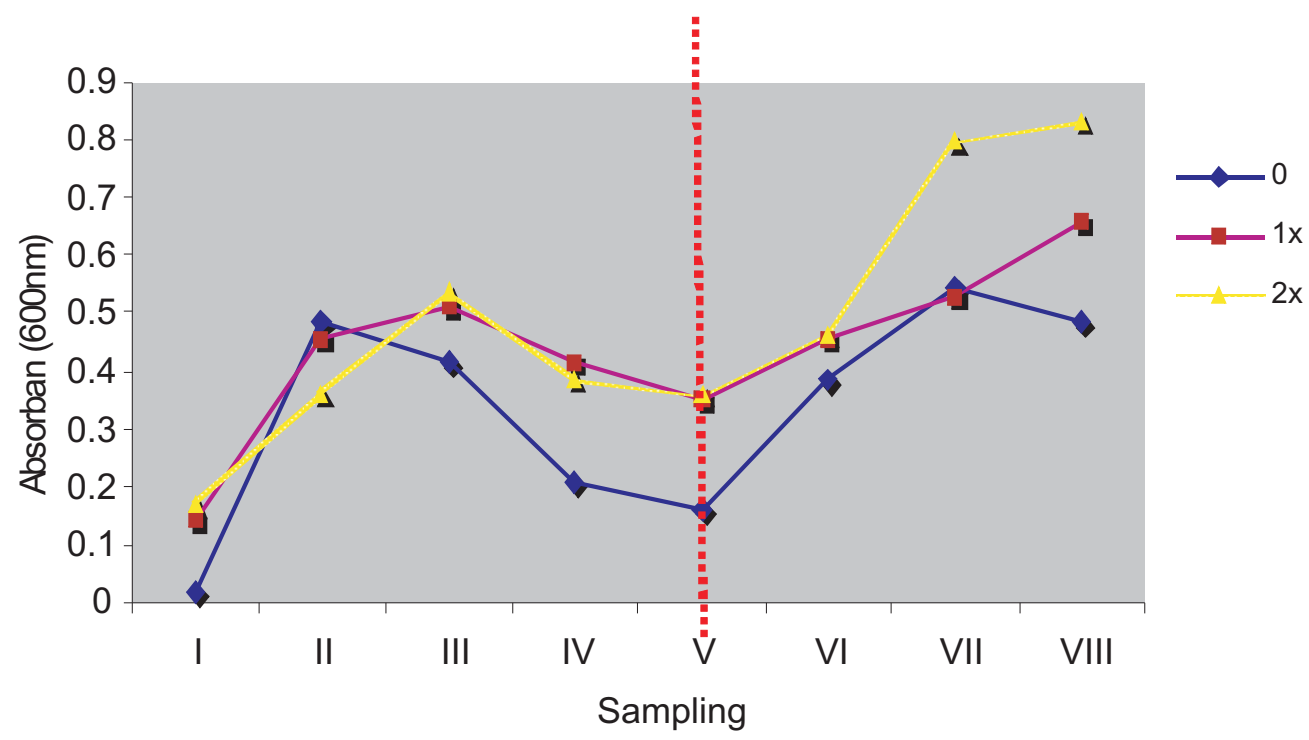

Gambar 4. Pola Pertumbuhan Kepadatan Konsorsium Mikroba 7). 


\subsection{Stabilitas Konsorsium Mikroba}

Stabilitas mikroba dimaksudkan sebagai kemampuan mikroba untuk hidup dan berkembang biak selama proses degradasi minyak. Pengamatan stabilitas konsorsium mikroba dapat dilihat dari perbandingan jumlah relatif setiap mikroba dalam sistem konsorsium yang mendekati nilai $1^{9)}$. Artinya, jumlah tiap mikroba yang tumbuh ketika disebar pada media NA relatif sama satu dengan yang lain. Apabila jumlah mikroba yang tumbuh relatif sama untuk setiap waktu pengamatan, dapat diasumsikan bahwa kompetisi yang terjadi diantara anggota konsorsium bersifat sinergis. Adapun sebaliknya, apabila jumlah mikroba yang satu dominan terhadap mikroba yang lain dapat dikatakan bahwa terjadi persaingan antagonis atau pertumbuhan mikroba yang satu menghambat pertumbuhan mikroba yang lain.

Tahap awal proses biodegradasi umumnya ditandai dengan peran mikroba penghasil biosurfaktan. Biosurfaktan yang dihasilkan berperan dalam pembentukan emulsi (misel) minyak-media 10), sehingga

(a)

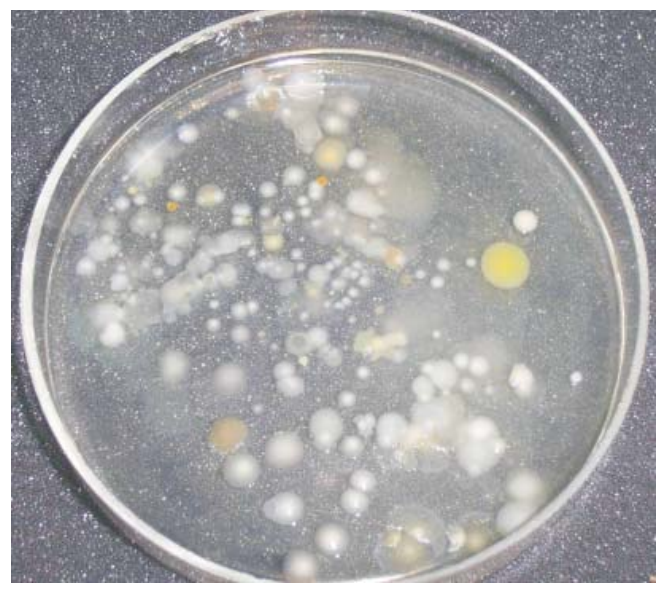

dapat dimanfaatkan oleh mikroba petrofilik sebagai sumber karbon. Oleh karena itu, mikroba yang terlihat dominan pada perlakuan $1 x$ dan $2 x$ kemungkinan besar adalah mikroba penghasil biosurfaktan. Umumnya terjadi kompetisi sinergis diantara mikroba penghasil biosurfaktan dan mikroba petrofilik. Hal tersebut ditandai dengan adanya jalur yang sinergis dari metabolit suatu mikroba (biosurfaktan) terhadap peningkatan aktivitas degradasi minyak oleh mikroba petrofilik ${ }^{10)}$.

Selanjutnya untuk mengetahui stabilitas konsorsium mikroba, pada penelitian ini diamati setelah hari ke-15 atau pada saat pengambilan sampel kelima. Sampel dari tiap perlakuan disebar pada media NA, kemudian diinkubasi pada suhu $30^{\circ} \mathrm{C}$ selama 48 jam. Profil mikroba yang

tumbuh terlihat pada Gambar 5. Apabila dilihat dari mikroba yang tumbuh pada perlakuan $2 x$, teramati bahwa pertumbuhan isolat dengan ciri morfologi berwarna putih dan berbentuk bulat lebih dominan dibandingkan mikroba lainnya. Hal yang sama teramati untuk perlakuan $1 \mathrm{x}$.

(b)

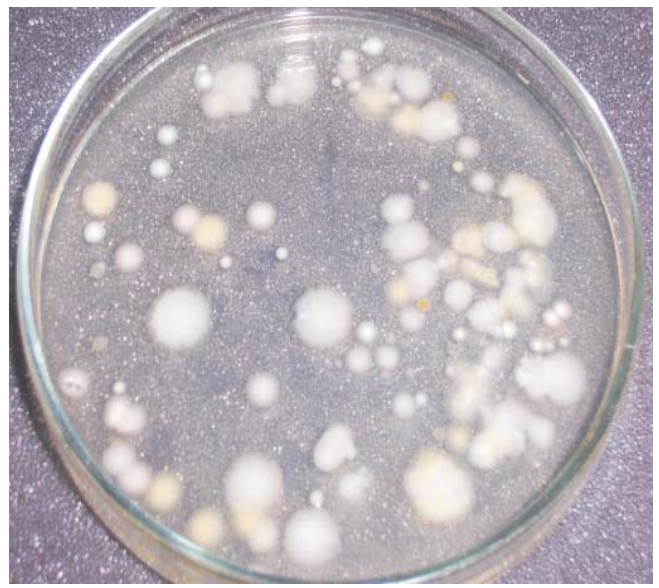

Gambar 5. Profil Mikroba perlakuan 2x (a) dan perlakuan 1x (b). 


\section{PENUTUP}

1. Pada uji batch kemampuan degradasi, pertumbuhan kosorsium mikroba menunjukkan peningkatan yang cukup baik, meskipun belum diikuti penurunan minyak yang signifikan.

2. Namun demikian secara keseluruhan terjadi peningkatan kepadatan mikrorba sejalan dengan tersedianya sumber karbon dari minyak yang terlarut dalam media kultur kajian tersebut. Kondisi ini diduga terjadi, karena mikroba yang tumbuh pada periode pengamatan I sampai $\mathrm{V}$ masih dalam tahap aklimatisasi, pada periode pengamatan VI sampai delapan kepadatan mikroba terus meningkat.

3. Pengamatan jumlah dan keragaman mikroba menunjukkan stabilitas konsorsium mikroba yang tumbuh relatif sama untuk setiap waktu pengamatan. Ini dapat diasumsikan bahwa kompetisi yang terjadi diantara anggota konsorsium bersifat sinergis.

\section{DAFTAR PUSTAKA}

1. Cookson, J.T Jr., 1995. Bioremediation Engineering: Design and Application. USA. McGraw-Hill, Inc.

2. Sarwoko, M., 2005. Seleksi Teknologi Pemulihan Untuk Ekosistem Laut Tercemar Mikroba. Seminar Nasional Teori dan Aplikasi Teknologi Kelautan ITS, Surabaya, 24 November 2005.

3. Okoh, A.I., 2006. Biodegradation alternative in the cleanup of petroleum hydrocarbon pollutants. Biotechnol. And Molecular Biology Review 1 (2):38-50.
4. Wongsa, P. et al., 2004. Isolation and characterization of novel strains of Pseudomonas aeruginosa and Serratia marcescens possessing high effeciency to degrade gasoline, kerosene, diesel oil, and lubricating oil. Cur Microbiol 49:415-422.

5. Malatova, K., 2005. Isolation and characterization of hydrocarbon degrading bacteria from environmental habitats in western New York state. Thesis: Department of Chemistry, Rochester Institute of Technology.

6. Ugochukwu, KC., Agha, NC., Ogbulie. 2008. Lipase activities of microbial isolates from soil contaminated with crude oil after bioremediation. African $\mathrm{J}$ Of Biotechnol. 7:2881-2884.

7. Komarawidjaja, W., 2009. Karakteristik dan Pertumbuhan Konsorsium Mikroba Lokal dalam Media Mengandung Mikroba Bumi. Jurnal Teknologi Lingkungan, PTL - BPPT. 10(1) : 114119.

8. Syakti, AD., 2008. Multi-Proses Remediasi Di dalam Penanganan Tumpahan Mikroba (Oil Spill) di Perairan Laut dan Pesisir. Seminar Bioremediasi PKSPL-IPB, 26 Februari 2008.

9. Gil, M, Haidour, A, Ramos, JL., 2000. Degradation of o-methoxybenzoate by a two-member consortium made up of a gram-positive Arthrobacter strain and a gram-negative Pantotea strain. Biodegradation 11:49-53.

10. Kumar, M., et al. 2006. Enhancement of oil degradation by co-culture of hydrocarbon degrading and biosurfactant producing bacteria. Polish J of Microbiol 55:139-146. 